\title{
„TO WIĘCEJ NIŻ POEZJA". MAŁŻEŃSTWO SAKRAMENTALNE W TWÓRCZOŚCI LITERACKIEJ HEINRICHA FEDERERA
}

Celem niniejszego artykułu jest analiza motywu małżeństwa w twórczości literackiej szwajcarskiego duchownego rzymskokatolickiego Heinricha Federera (1866-1928). Nie do uniknięcia są przy tym pytania o ideę promowania wartości chrześcijańskich poprzez dzieło literackie, czy też precyzyjniej - o sens podejmowania prób przełożenia na język literacki głębi doświadczenia wiary. Stąd warto pomimo zastrzeżeń wysuwanych przez Thomasa S. Eliota odnośnie do badań nad literaturą pióra autorów, którzy „mają szczerą chęć przysłużyć się sprawie religii” - przyjrzeć się bliżej tej twórczości „niedoczytanej” i jej wkładowi w odnowę piśmiennictwa o charakterze teologicznym. Warto podkreślić wpływ na twórczość Federera uznanego w kręgach inteligencji niemieckojęzycznej czasopisma „Hochland" oraz odniesienia do propagowanej przezeń idei odrodzenia literatury czerpiącej swoje inspiracje z tradycji katolickiej. Utwory Federera czytane poza macierzystym kontekstem (i niezależnie od pierwotnej recepcji) mogłyby zostać potraktowane przez wspólczesnego czytelnika głównie jako małowartościowa proza obyczajowa, dlatego nie bez znaczenia są odwoływania w niniejszym artykule do ówczesnego kontekstu kulturowo-religijnego.

\section{INFORMACJE BIOGRAFICZNE}

Heinrich Federer urodził się 6 października 1866 roku w szwajcarskim Brienz. Był synem rzeźbiarza i nauczyciela, Paula Federera, i jego żony Vereny (z domu Nägeli). Ojciec uchodził powszechnie za utalentowanego artystycznie wagabundę, nieprzystosowanego do życia w rodzinie. Matka krótko przed ślubem z Paulem

1 Th. Stearns Eliot, Religia i literatura, w: Szkice literackie, red. W. Chwalewik, PAX, Warszawa 1963, s. 110. 
przeszła z wyznania ewangelickiego na katolicyzm. Heinrich Federer od dziecka chorował na astmę, co uniemożliwiało mu - ze względu na liczne pobyty w sanatoriach - systematyczną edukację. W latach 1873-1880 uczęszczał do szkoły podstawowej w Sachseln i szkoły realnej w Sarnen. Rok później podjął naukę w kolegium benedyktyńskim w Sarnen, a następnie przez rok uczęszczał do liceum w Schwyz. W 1886 roku stracił oboje rodziców. Po maturze (1888) studiował teologię w seminarium duchownym w Eichstätt (1888), potem w Lucernie (18881889), we Fryburgu Szwajcarskim (1890-1891) oraz w St. Georgen (1892-1893). Udzielał się aktywnie w Szwajcarskim Związku Studentów [Schweizerischer Studentenverein], gdzie w wydawanym przez niego biuletynie „Monat-Rosen” opublikował swoje pierwsze utwory liryczne.

Po święceniach kapłańskich przyjętych w 1893 roku w St. Gallen objął posadę wikariusza w parafii Jonschwil, gdzie spędził sześć lat, publikując felietony w czasopismach: „Wilder Bote”, „Alttoggenburger”, „Ostschweiz” i „Vaterland”. Od 1899 roku pracowal jako redaktor w katolickim czasopismie „Neue Zürcher Nachrichten" oraz jako ojciec duchowy w Domu św. Elżbiety [Elisabethheim]. W tym samym roku wygłosił podczas Dnia Katolika w St. Gallen referat zatytułowany Über den unchristlichen Roman. Od roku 1898 Federer czynnie włączył się w działania zmierzające do odrodzenia literatury czerpiącej z tradycji chrześcijańskiej, czego świadectwem jest seria artykułów w czasopismie „Vaterland”. Do tekstów Federera odwoływał się nierzadko powstały w 1903 roku miesięcznik inteligencji chrześcijańskiej „Hochland”. Ogólne zaskoczenie w kręgach literackich wywołała postawa szwajcarskiego pisarza w 1910 roku, kiedy to - najprawdopodobniej pod naciskiem biskupa Chur, Georgiusa Schmida von Grüneck - wystąpił (pod pseudonimem Senex) nie tylko przeciwko dotychczas popieranym przezeń pewnym tendencjom modernistycznym w literaturze, lecz również przeciwko ideom odnowy literatury propagowanym przez „Hochland”.

W 1902 roku Federer został oskarżony o kontakty homoseksualne z jednym ze swoich uczniów, jednakże ze względu na brak dostatecznych dowodów winy, sprawę umorzono. Kościół pozbawił go jednak prawa do wykonywania czynności duszpasterskich - odtąd szwajcarski kapłan odprawiał Eucharystię (na mocy biskupiej dyspensy ${ }^{2}$ ) wyłącznie w odosobnieniu, we własnym mieszkaniu ${ }^{3}$.

Od 1903 roku utrzymywał kontakty z akademicko-naukowym towarzystwem „Renaissance Zürich”, gdzie opublikował humorystyczne studium Der Tod der

2 Por. List Federera do dr. Georgiusa Schmida von Grüneck (Zürich, 20.11.1909) w sprawie dyspensy przy celebrowaniu mszy św. Ordynariusz zwrócił się w tej sprawie pisemnie do Piusa X (07.12.1909). Por. Schweizerisches Literaturarchiv Federer (SLA-FED), sygnatura B-01-SCHM.

3 W obronie Federera oficjalnie stanęły jedynie „Zürcher Nachrichten” (Zum Fall Federer, nr 64 z 09.08.1902), odpierając zarzuty stawiane oskarżonemu przez „Neue Zürcher Zeitung” (m.in. złamanie celibatu). Usprawiedliwienia dla zaistniałego wydarzenia szukano przede wszystkim w inklinacjach rodzinnych oskarżonego. 
Renaissance $^{4}$. W 1905 roku uczestniczył w audiencji u papieża Piusa X. W 1909 roku zadebiutował jako pisarz, otrzymując w ogłoszonym przez niemieckie czasopismo „Daheim” konkursie literackim pierwsze miejsce za publikację noweli Vater und Sohn im Examen. Dużą popularność wśród czytelników przyniosły mu opublikowane w 1911 roku tomy opowiadań Berge und Menschen oraz Lachweiler Geschichten. Od tego czasu kolejne utwory przyjmowane były w kręgach czytelniczych najczęściej entuzjastycznie, a Federer z czasem zapracował na miano uznanego prozaika.

W 1919 roku za swoją twórczość literacką otrzymał tytuł honoris causa uniwersytetu w Bernie, a w 1924 roku - Nagrodę im. Gottfrieda Kellera, przyznawaną przez Fundację im. Martina Bodmera. W 1926 roku Federer otrzymał nagrodę za całokształt twórczości, przyznawaną przez Szwajcarską Fundację im. Schillera, rok później został honorowym obywatelem miasta Sachseln. W latach 1919-1928 mieszkał przy ulicy Bolleystrasse $44 \mathrm{w}$ Zurychu, gdzie do dzisiaj znajduje się poświęcona mu tablica pamiątkowa. Zmarł 29 kwietnia 1928 roku i został pochowany na cmentarzu Rehalp w Zurychu. Jego spuścizna znajduje się w Szwajcarskim Archiwum Literatury w Bernie 5 .

\section{MAEŻEŃSKI ZWIĄZEK SAKRAMENTALNY W TEKSTACH FEDERERA}

Heinrich Federer odnosi się w swojej twórczości do małżeństwa rozpatrywanego wyłącznie przez pryzmat sakramentalny. Ukazana przez niego w sposób realistyczny koncepcja związku kobiety i mężczyzny uwzględnia ówczesne uwarunkowania kulturowe i ówczesny stan wiedzy dotyczącej psychiki ludzkiej.

W omawianej twórczości obecne są aluzje do dwóch dominujących na przełomie XIX i XX wieku tendencji w Kościele, związanych z postrzeganiem kwestii małżeństwa. Pierwsza z nich charakteryzowała się skrajną nietolerancją wobec spraw płci i wszelkich przejawów aktywności seksualnych, traktowanych nawet w sakramentalnym związku jako zdradę miłości wobec Boga. W tym nurcie silne były również wpływy neoplatońskie, które przyczyniły się do powstania grup dziewic i wdów kanonicznych. Niemało było też pism sławiących wyższość ascezy seksualnej nad związkiem małżeńskim. W drugiej koncepcji, opierającej się na pismach św. Tomasza z Akwinu, dochodziła do głosu nauka Arystotelesa o konieczności uwzględnienia cielesno-duchowej natury ludzkiej, stąd małżeństwo traktowane było jako kompromis między postulatem wyłącznej miłości do Boga a zmysłowością człowieka. Warto nadmienić przy okazji trwający prawie przez cały

4 Por. H. Federer, Der Tod der Renaissance, ,Jahresbericht der Renaissance”, Zürich 1909/10, s. $1-5$.

5 Spuścizna składa się z piśmiennictwa Federera przechowywanego do 2004 roku w Bibliotece Kantonalnej w Sarnen i ze zbiorów Caspara Kindlimanna (przekazane archiwum w 2007 roku). 
XIX wiek spór o jurysdykcję nad małżeństwem chrześcijańskim. W sprawie wyłącznej kompetencji Kościoła odnośnie do ważności małżeństwa wypowiadał się m.in. papież Pius IX w Syllabusie (1864) oraz w przemówieniu Acerbissimum vobiscum (1852). Do kwestii rozdzielenia kontraktu małżeńskiego między władzę świecką a kościelną nawiązywał też w 1880 roku papież Leon XIII w encyklice Arcanum divinae sapientiae: „Zważyć też należy charakter Sakramentu, przez który małżeństwo chrześcijańskie wyniesione zostało do niezrównanej godności. Stanowienie zaś o Sakramentach i normowanie rzeczy, które ich dotyczą, tak dalece z woli Chrystusa Pana należy wyłącznie do zadań Kościoła, że nawet pomyśleć się nie da, aby ta władza albo jej część, choćby najmniejsza, była przeniesiona na organy państwowe"6.

Leon XIII, podobnie jak jego bezpośredni poprzednicy, nie analizuje głębiej istoty sakramentalnego wymiaru małżeństwa i jego związków z historią zbawienia oraz tajemnicą Kościoła?. W Arcanum divinae sapientiae przestrzega natomiast przed zawieraniem małżeństw mieszanych, co może być „poważną przeszkodą w dobrym wychowaniu dzieci” $\mathrm{i}$ w traktowaniu wszystkich religii jako równoważne. Nadmienia przy tym, że małżeństwa „o tyle nacechowane są spokojem i trwałością, o ile małżonkowie przepojeni są duchem religii i z niej czerpią natchnienia dla życia swego; religia daje wytrwałość i męstwo; ona sprawia, że znosi się nie tylko spokojnie, lecz nawet ochoczo wady, jeżeli jakie są w osobach, że się znosi różnice obyczajów i temperamentów, że się dźwiga odważnie ciężar trosk macierzyńskich [...], a nawet utrapienia"".

Za czasów Federera małżeństwo było traktowane w Kościele rzymskokatolickim bardziej przedmiotowo niż personalistycznie, zaś sama teologia naznaczona była silnym wpływem kazuistyki i moralistyki. Szwajcarski kapłan odwoływał się w opisach perypetii małżeńskich wykreowanych przez siebie postaci literackich przede wszystkim do przekazu biblijnego, tzn. bezpośrednio do orędzia ewangelicznego. Dobitnie podkreśla dwa wzajemnie się warunkujące wymiary ,agape”: miłość Boga do człowieka oraz miłość człowieka do bliźniego. Obydwie kategorie nie odnoszą się do rzeczywistości odrębnych, a zatem ich opis zakłada uwzględnienie faktu wzajemnego przenikania. Małżeństwo traktowane jest przez Federera w kategoriach związku na wzór przymierza Boga z człowiekiem. Co więcej, jego przepojone realizmem i niezwykle sugestywne obrazy więzi rodzinnych i społecznych, jakie kreśli w swoich utworach, mogą fascynować niezależnie od tego, czy będą rozpatrywane w kategoriach etyki chrześcijańskiej.

Leon XIII, Arcanum divinae sapientiae, http://www.nonpossumus.pl/encykliki/Leon_XIII/arcanum_divinae_sapientiae/ads.php (28.02.2018).

7 Pisze o tym szerzej m.in. J. Grześkowiak, ,, Tajemnica to jest wielka”. Sakramentalne przymierze malżeńskie, Uniwersytet Opolski, Opole 2010, s. 58-59.

8 Tamże, s. 45.

9 Tamże, s. 42. 
Miłość i religia - tematy niemalże komparatystyczne w twórczości Federera są najczęściej wykładnią moralnego zaangażowania pisarza. Teologia małżeństwa, wyłaniająca się z jego pism, osadza się na kilku przesłankach. Po pierwsze, związek ten, pobłogosławiony przez Kościół, jest nierozerwalny. Przekazuje tę prawdę nie tylko w sposób pośredni w tekstach autobiograficznych Am Fenster (1927) i Aus jungen Tagen (1928), lecz również bezpośrednio w powieści autobiograficznej Mätteliseppi (1916). Proboszcz Antonius Molin w rozmowie ze zrozpaczoną Vereną Spichtiger, żoną beztroskiego Paula, porównuje związek małżeński do delikatnego haftu, któremu w każdej chwili grozi zerwanie. Element męski nadaje mu stałe i równomierne kontury, a pierwiastek żeński, symbolizowany przez nitki cienkie, ale mimo to wytrzymałe, decyduje w dużej mierze o trwałości przedmiotu. Dodaje przy tym, że każdą rozerwaną tkaninę, a tym bardziej suknię ślubną, można ponownie zszyćc ${ }^{10}$. Ta metaforyka i doprowadzony do artyzmu realizm zostaje celowo wzbogacony przysłowiami i powiedzeniami, świadczącymi o wyłapywaniu przez Federera prostej i ewangelicznej mądrości ludowej. Przywołany duchowny posługuje się też szerokim, kompleksowym sposobem oddziaływania na swoich wiernych. Osiąga swoje cele jednak przede wszystkim drogą perswazji, apelowania do ich uczuć i wyobraźni. I tak, przekonuje, że miłość wymaga czegoś więcej niż tylko sentymentalnej aury macierzyństwa. Religijny model życia propaguje też wśród nich za pomocą wychowania, m.in. przez dostarczanie odpowiednich lektur, przez barwne ceremonie religijne oraz bogato przystrojony kościół. Powstaje wrażenie, że świadomie wprowadzona ekspresja, poetyckie obrazowanie i w takiej samej konwencji rysowane tło, nie tylko koresponduje z cechami postaci literackich, lecz wyraźnie je wzmacnia i tworzy jednoznaczną w wymowie aurę wartości. Zabiegi te przemawiają do kobiet, które cierpliwie znoszą trudy małżeńskiego pożycia. Należą do nich m.in. tytułowa bohaterka powieści Regina Lob (1911), pani Sette (Berge und Menschen; 1911), Agnes (Pilatus; 1912) oraz Milli (Papst und Kaiser im Dorf; 1924). U większości z nich prawdziwym probierzem miłości jest ich zachowanie się podczas choroby współmałżonka. Wierność mężowi okazuje też Rufa (Alonzo Brigone; z tomu opowiadań pt. Wander- und Wundergeschichten aus dem Süden 1924), która w geście solidarności ze swoim mężem podejmuje decyzję wraz z nim odsiedzenia kary więzienia ${ }^{11}$. Federer w opowiadaniu Patria (1917) zdaje się wkładać w usta jednego z katolickich studentów słowa Kościoła na temat związku sakramentalnego: „To więcej niż poezja [...], to jest sakrament! Oznacza to: Pozostaniecie złączeni na zawsze w miłości, [...] złączeni w wiernym obowiązku, tak że nic was nie może

10 Cyt. za: H. Federer, Mätteliseppi, Grotesche Verlagsbuchhandlung, Berlin 1931, s. 200-201.

11 Por. H. Federer, Wander-und Wundergeschichten aus dem Süden, Grotesche Verlagsbuchhandlung, Berlin 1924, s. 1-89. 
rozłączyć”12. Tak pojmowana „agape” jawi się jako najpełniejszy przejaw miłości prawdziwej, pełnej poświęcenia, nieskończonej, ciągle dojrzewającej i definitywnej. Dzięki jej zakotwiczeniu w Bożej miłości przestaje ona być jedynie uczuciem, gdyż dochodzi w niej do postawy aktywizującej wolę i intelekt. Po drugie, małżeństwo sakramentalne to znacznie więcej niż kontrakt o charakterze materialnym, zawierany nierzadko zgodnie z sugestią rodziców lub innych krewnych. Związek pobłogosławiony przez Boga powinien być oparty na rozumnej decyzji, co autor ilustruje w opowiadaniach Sibilla Pagni und Tadeo Amente, Mala Golzi, die Buchbinderin in Todi, Alonzo Brigone (1924) oraz Spitzbube über Spitzbube (1921). Jednocześnie pisarz podważa powszechnie panujące ówcześnie przekonanie, że opiekunowie wiedzą lepiej, z kim połączyć młodych. Autor ukazuje z drugiej strony, że bazowanie jedynie na uczuciach może okazać się zgubne ze względu na ich zmienność. Zgodnie zatem z tradycyjną kulturą i przekazem kościelnym małżeństwo miało być oparte na wzajemnym szacunku i zgodności dążeń. Federer był również zdania, że żarliwość religijna nie zależy ani od stopnia posiadania wiedzy teologicznej, ani od wyznania. W liście do Hansa Osera pisze o głębokiej wierze swojej matki-ewangeliczki, która to po przejściu na katolicyzm otrzymała jeszcze bardziej wyraziste kontury i umocowanie metafizyczne, podczas gdy wiara jego ojca, wychowanego w atmosferze ortodoksji katolickiej, pozostała do końca fasadowa ${ }^{13}$. Stąd też o popularności tekstów Szwajcara - według Paula Kamera, „pierwszego ekumenika swoich czasów” - decydował w I połowie XX wieku fakt, że były (i są) one „wyzwalająco nieteologiczne” i „niemisjonarskie” ${ }^{\prime 4}$. Odwołania Federera do tradycji patrystycznej i przedtrydenckiej, które nie uznawały rozdzielania zagadnień dogmatycznych i moralnych, stoi w sprzeczności z powyższym twierdzeniem. Co więcej, jego twórczość jak najbardziej wpisuje moralność chrześcijańską w kontekst dogmatyczny i eklezjologiczny. O swojej matce, stanowiącej przykład stateczności, wierności małżeńskiej i ortodoksji obyczajowej, pisze on również w sposób następujący: „I zdarzył się rzeczywiście cud. W trzydziestoletniej kobiecie rozwinęła się siła zdolna pokochać, poświęcić się i służyć. Ta nowa moc wydawała się jej przez długi czas w obliczu wielu rozczarowań prawdziwie uszczęśliwiająca" ${ }^{15}$. Wprawdzie pisarz ukazuje swoją matkę jako osobę doznającą w małżeństwie wielu cierpień, to jednak nie przedstawia on jej jako osoby bezwarunkowo podporządkowanej mężowi, lecz jako kobietę świadomą

12 Por. H. Federer, Patria! Eine Erzählung aus der irischen Heldenzeit, Herder Verlag, Freiburg i.Br. 1917, s. 30. O ile nie zaznaczono innego tłumacza, wszystkie cytaty w thumaczeniu autorki artykułu.

13 Por. H. Oser, Heinrich Federer. Aus Briefen und Erinnerungen, Räber, Luzern-Leipzig 1928, s. 10.

14 P. Kamer, Postowie do powieści Federera „Pilatus”, Ex Libris, Zürich 1981, s. 372.

15 Cyt. za: H. Federer, Am Fenster. Jugenderinnerungen, Grotesche Verlagsbuchhandlung, Berlin 1927, s. 26. 
swojej wartości i potrafiącą - nawet pomimo trudu - samodzielnie zadbać o rodzinę. U Federera dominuje motyw miłości trudnej, zmuszającej małżonków do pokonywania różnych przeszkód na drodze do wspólnego zadowolenia. $Z$ drugiej jednak strony, demaskuje on przekonanie, że uczucie ma szansę przetrwać tylko wówczas, gdy napotyka konkretne przeszkody.

Doświadczanie sakralności odbywa się zdaniem autora poprzez element cielesny i zmysłowy. Federer nie deprecjonuje ciała jako siedliska nieczystości, lecz ujmuje je najczęściej jako domenę zmysłów. Stąd estetyzacja tego obszaru służy mu do odzyskania poczucia harmonii między sferą duchową i cielesną. Poruszając zagadnienia odnoszące się do zagadnień metafizycznych, pióro Federera wolne jest od patosu. Jest to jednocześnie język odwołujący się niekiedy do celnej poetyckiej metafory dla uwypuklenia przeżyć i postaw, ze swojej natury trudno poddających się werbalizacji. Religijność człowieka, wyrażająca się m.in. w uczestnictwie w życiu sakramentalnym Kościoła, nie jest tylko rezultatem różnych aktów intelektualnych, lecz rodzajem ,sposobu życia”. Tym samym Federer unika bezpośrednich nawiązań do dogmatyki kościelnej, ukazując jednocześnie realizację prawd ewangelicznych poprzez konkretne wybory, decyzje i czyny wykreowanych przezeń postaci literackich. Co więcej, za prawdziwych teologów życia uważa tych ludzi, którzy w życiu codziennym (również na sposób ,świecki”) uwierzytelniają chrześcijaństwo.

Podołaniu zobowiązaniom małżeńskim sprzyja dobre rozeznanie, ale i praktykowana przedślubna czystość, co pisarz obrazuje na przykładach związku Sigi und Mili, Loreley i Johannesa (Papst und Kaiser im Dorf) oraz Marxa i Agnes (Pilatus). Przesłanki te gwarantują w dużym stopniu, że związek będzie miał pozytywny wpływ na obyczajowość małżonków i na temperowanie ich porywczości. To dzięki ,agape” możliwe staje się powstrzymanie groźnych dla związku żądz „erosa” w postaci egoizmu i porywczości. Narzucając narzeczonym pewne ograniczenia Kościół - zdaniem Federera - przyczynia się do rozwoju dyscypliny moralnej i do kierowania ich energii ku innym, społecznym zadaniom i celom. Dodać należy, że pisarz nie był rygorystą. W swoich utworach - co obrazuje najpełniej opowiadanie Der Erzengel Michael - nakłania do korzystania z życia oraz do doszukiwania się w miłości jej uroków, barw i smaków. Również zmysłowość co wynika np. z opowiadania Manöver - może prowadzić do miłości pojętej pełniej i bardziej duchowo. U Federera ,agape” i „eros” nie są zatem kategoriami przeciwstawnymi, choć ta druga powinna być podporządkowana pierwszej. „Eros”, jako przynależny naturze ludzkiej, jest bowiem siłą napędową poszukiwań drugiej osoby, co umożliwia powstanie związku. Doceniona została również rola przyjaźni między małżonkami, która odpowiadała pojęciu miłości życzliwej.

Po trzecie, wierny zaleceniom Leona XIII i powszechnej praktyce odradzania związków mieszanych, Federer ukazuje w opowiadaniu Patria losy dwóch kochających się osób - katolika Roberta Emmeta i ewangeliczki Sary - którzy ze względu 
na różne wyznania nie mogą wstąpić w związek sakramentalny. Autor zwraca przy tym uwagę na to, że małżeństwo zakłada doskonałą jedność dwojga ludzi, która w małżeństwach mieszanych, ze względu na różnice zdań w sprawach religii, nie może być osiągnięta, co często prowadzi do konfliktów, zwłaszcza gdy przemija pierwsze uczuciowe zaangażowanie. Federer nigdy jednak nie porusza w swojej twórczości tematu konwersji jednego z małżonków. Sprawy te nie były mu jednak obce, gdyż jego matka wychodząc za mąż za Paula Federera przeszła na katolicyzm i - co wynika z tekstów autobiograficznych - przyjęła to wyznanie z potrzeby serca i z pełnym zaangażowaniem. Mimo to jej związek daleki był od ideału jedności małżeńskiej.

Istotnym wyznacznikiem prozy szwajcarskiego kapłana, nadającym jej osobliwe właściwości, jest sposób prezentowania przezeń układu zdarzeń świata przedstawionego, budowanie wzajemnych relacji między kochającymi się osobami oraz tworzenie wątków, składających się na całość akcji utworu. Federer próbuje stworzyć taki przekaz, który byłby czytelny dla odbiorcy, a zarazem wiarygodny. Nie sposób nie dostrzec tu powszechnie stosowanego w literaturze zaangażowanej pewnego czynnika, wyraziście określającego postawę bohatera. Buduje on czytelny topos, harmonizując jednocześnie świat jego wewnętrznych przeżyć i przekonań z zewnętrzną płaszczyzną działań, która - dostosowana niejako do cnót i wad tejże postaci literackiej - tworzy w ten sposób, na zasadzie kontrastu, przestrzeń. Ona to wyzwala uczucia aprobaty lub dezaprobaty dla lansowanych wartości. Ale i ta konwencja literacka nie jest wolna od nieścisłości. Z jednej bowiem strony autor ukazuje radość płynącą z sakramentalnego związku, z drugiej strony ukazuje on, że taka miłość jest bardzo trudno osiągalna.

W zakładającej elementy dydaktyki konwencji literackiej Federera nie brakuje niekwestionowanych autorytetów, które nie tylko stanowią godny do naśladowania przykład, lecz również występują w roli interpretatora i komentatora norm religijnych, ukazując nagrodę bądź karę zarówno w kategoriach doczesnych, jak i wiecznych. Są nimi nierzadko duchowni, ale i nauczyciele czy też - choć rzadziej - przedstawiciele innych warstw społecznych. Oni to potwierdzają, że tradycyjne wartości rodzinne, wierność i odpowiedzialność oraz respektowanie kulturowo określonej roli kobiecości i męskości, decydują o szczęśliwym związku.

\section{TEOLOGIA JAKO INTEGRALNY SKŁADNIK DZIEŁA LITERACKIEGO}

W formach narracyjnych Federera zaobserwować można zjawisko „resakralizacji literatury", będące następstwem dwóch istotnych procesów na przełomie XIX i XX wieku: widoczną w sposób szczególny w niemieckiej kulturze mieszczańskiej „desymbolizację” świata, połączoną z dążeniami do jej „odczarowania” oraz z daleko idącą i związaną z postawą obronną wobec Kulturkampfu formali- 
zację świadomości religijnej. Choć Federer rezygnuje w swoich utworach z języka naukowego dyskursu, to jednak teologia wpisana jest w jego twórczość i stanowi integralny składnik jej literackości. Wobec ograniczonego przygotowania teologicznego odbiorców, należy w utworach Federera wyraźnie zrozumieć różnicę pomiędzy tym, co stanowi nienaruszalne dziedzictwo wiary, a własnymi poglądami autorów, na co zwraca uwagę Jörg Seip, odnosząc się - na przykładzie tekstów publicystycznych szwajcarskiego pisarza dotyczących odnowy literatury katolickiej - do nierozwiązywalnego konfliktu między Urzędem Nauczycielskim Kościoła a literaturą piękną ${ }^{16}$. Zadaniem teologa, jako świadka wiary jest mieć we wszystkim, co pisze i czego naucza, na uwadze to podwójne odniesienie: do Magisterium i do wspólnoty wierzących. Dobór określonych treści dogmatycznych, służących autorowi za motyw literacki, wyraża tym samym jego pogląd na rzeczywistość wiary. Stąd uzasadnione było ukazanie przezeń jej głównych prawd odnoszących się do Bożego ojcostwa, m.in. sakramentów jako widzialnych znaków obecności Boga. W twórczości literackiej Federera przewija się motyw głoszonych przez Kościół zasad moralnych, na jakich zbudowana i w świetle których praktykowana jest wiara. Poruszane są również tematy odnoszące się do eschatologii w kontekście nowej rzeczywistości.

Literackie zapożyczenia wątku biblijnego nie są przypadkowym naśladownictwem, lecz wypadkową tożsamości epoki oraz osobowości autora, stąd zestawienie konkretnych efektów twórczych z prawzorem biblijnym nie dokonuje się bez pewnych napięć między wymienionymi czynnikami. I tak, w tekstach Federera spotykamy utwory, których biblijność jest czasami czymś „uzupełniającym”, a innym razem istotnym, tzn. niepolegającym wyłącznie na figuralnych analogiach. Większość tekstów pozostaje w kręgu szeroko rozumianych zagadnień religijnych, a nawiązania do ksiąg biblijnych stanowią założenie programowe autora; dotyczą zwykle pewnych fragmentów oraz służą do wypełniania moralistycznego przesłania tekstu. Warto dodać, że różnego typu aluzje biblijne nierzadko krzyżują się ze sobą w ramach pojedynczego utworu. Dotyczy to takich zabiegów, jak: bardziej rozpoznawalne lub zgrabnie ukryte aluzje do sytuacji biblijnych, przywołania biblijnej symboliki oraz parafrazy tekstu biblijnego. Charakterystyczne jest przy tym zakotwiczenie w szczególe, a tym samym niechęć do ujęć abstrakcyjnych. Zresztą sama Biblia stroni od teoretyzowania i postrzega konkretne wydarzenie jako pewnego rodzaju parabolę. Konsekwencją takiego zabiegu jest wyrażanie prawd odwiecznych i niewyrażalnych w kategoriach uchwytnych poprzez codzienne doświadczenie ${ }^{17}$.

16 Por. J. Seip, Einander die Wahrheit hinüberreichen. Kriteriologische Verhältnisbestimmung von Literatur und Verkündigung, Echter Verlag, Würzburg 2002, s. 126-129.

17 Więcej na ten temat w: A. Chylewska-Tölle, Między przestrzeniq wiary a poetyka wyznania. Szkice o niemieckojęzycznej literaturze chrześcijańskiej, Wydawnictwo Uniwersytetu Kazimierza Wielkiego w Bydgoszczy, Bydgoszcz 2010, s. 94-104. 


\section{ZAKOŃCZENIE}

Na twórczość literacką Federera (również odnośnie do sakramentu małżeństwa) można spojrzeć w kategoriach korekty (lub też uzupełnienia) ogólniejszego modelu wychowania religijnego na przełomie XIX i XX wieku. Model, który - wbrew chrześcijańskiej wizji człowieka i wynikającej z niej podstawowej zasady pedagogiki, głoszącej, że człowiek jest istotą wolną, i tylko czyn będący rezultatem wolnego wyboru zasługuje na miano czynu ludzkiego - opierał się na wyrabianiu u wiernych dobrych przyzwyczajeń, wdrażaniu ich do posłuszeństwa, przy jednoczesnym pomniejszaniu znaczenia wiedzy, kompetencji i krytycznego myślenia. Jego działalność przypadła na czas dużej czujności cenzorów kościelnych, którzy namawiali do roztropności oraz do unikania publikacji, w których zawarte byłyby subiektywne poglądy. Podejrzane były zwłaszcza teksty traktujące wiarę jako wydarzenie epifaniczne, na styku historii i transcendencji. Twórczość Federera nie budziła żadnych większych wątpliwości w kręgach kościelnych, co więcej: skoncentrowane na zagadnieniach społeczno-obyczajowych teksty te spotykały się z powszechnym uznaniem. Warto odwołać się w tym miejscu do głosów podnoszonych w latach trzydziestych ubiegłego wieku, także w środowisku autorów wywodzących się z nurtu ,renouveau catholique”. François Mauriac (1885-1970) i jego zwolennicy głosili istnienie konfliktu między pisarzem a człowiekiem wierzącym. Ten pierwszy powinien zachowywać się wobec dobra i zła w sposób neutralny, natomiast ten drugi nie może być - przynajmniej w sensie poznawczym - obiektywny wobec zła. Jego zadaniem jest demaskowanie go i jednocześnie obrona stanu posiadania Kościoła przed licznymi niebezpieczeństwami ze strony czynników niekatolickich. Natomiast Federer wiązał szanse odrodzenia kultury europejskiej z przekroczeniem paradygmatu religijności ściśle wyznaniowej. Obszar religii wyznaczają ich zdaniem wszelkie ludzkie poszukiwania Boga, życie w wierze jest natomiast ich odpowiedzią na Objawienie, będące darem transcendentnego Ty. Cechą charakterystyczną tekstów literackich Federera jest świadome osłabienie opozycji pomiędzy „religią” a „wiarą”. Odwołując się do Emmanuela Lévinasa, który to napięcie zuniwersalizował, można stwierdzić, że nie ma w jego twórczości konfliktu między „potrzebą” [fr. beoin, niem. Bedürfnis], a „pragnieniem” [fr. désir, niem. Begehren] ${ }^{18}$; natomiast wyczuwa się w tych narracjach puls żywego doświadczenia wiary. Dostępne teksty o charakterze autobiograficznym Federera nie dowodzą też klinczu, w jakim rzekomo miałby się on znaleźć, podejmując próby pogodzenia swojego kapłaństwa z misją głoszenia Ewangelii w sposób niestandardowy, czyli przez pryzmat literatury pięknej.

18 Por. E. Levinas, Totalität und Unendlichkeit. Versuch über die Exeriorität, Alber, Freiburg München 1987. 
Niewidoczne są też w tych narracjach jakiekolwiek napięcia na poziomie instytucjonalnym, tzn. między „świadomością religijną” a „więzią kościelną”, wybrzmiewa natomiast pytanie o kompromis między wymaganą komunikatywnością i artystycznymi aspiracjami. Federer nie wyobrażał sobie, by zaproponowana przezeń koncepcja, wiążąca wiarę z doświadczeniem ładu i harmonii, miała swoje źródła usytuowane poza religią.

\section{Bibliografia}

Chylewska-Tölle A., Między przestrzeniq wiary a poetyka wyznania. Szkice o niemieckojęzycznej literaturze chrześcijańskiej, Wydawnictwo Uniwersytetu im. Kazimierza Wielkiego w Bydgoszczy, Bydgoszcz 2010.

Federer H., Alonso Brigone, w: Wander- und Wundergeschichten aus dem Süden, Grotesche Verlagsbuchhandlung, Berlin 1924, s. 1-89.

Federer H., Aus jungen Tagen. Nachgelassene Kapitel zur Lebensgeschichte, Grotesche Verlagsbuchhandlung, Berlin 1928.

Federer H., Berge und Menschen, Grotesche Verlagsbuchhandlung, Berlin 1911.

Federer H., Der Erzengel Michael. Aus meines Vaters Notizenbuch, w: Lachweiler Geschichten. Gesammelte Werke, Grotesche Verlagsbuchhandlung, Berlin 1931, T. 1., s. 161-182.

Federer H., Der Tod der Renaissance, „Jahresbericht der Renaissance”, Zürich 1909/10, s. 1-5

Federer H., Die Manöver. Eine schweizerische Soldatengeschichte, w: Lachweiler Geschichten. Gesammelte Werke, Grotesche Verlagsbuchhandlung, Berlin 1931, T. 1., s. 183-244.

Federer H., Mala Golzi, die Buchbinderin in Todi, w: Unter südlichen Sonnen und Menschen. Sechs Novellen von Heinrich Federer, Verlag der Buchgemeinde Bonn, Bonn-Berlin 1929, s. 225-307.

Federer, H., Mätteliseppi, Grotesche Verlagsbuchhandlung, Berlin 1931.

Federer H., Papst und Kaiser im Dorf, Grotesche Verlagsbuchhandlung, Berlin 1924.

Federer H., Patria! Eine Erzählung aus der irischen Heldenzeit, Herder Verlag, Freiburg i.Br. 1917.

Federer H., Regina Lob, Grotesche Verlagsbuchhandlung, Berlin 1925.

Federer H., Sibilla Pagni und Taddeo Amente, w: Das letzte Stündlein des Papstes. Umbrische Reisegeschichtlein, Salzer, Heilbronn 1950, s. 69-85.

Federer H., Spitzbube über Spitzbube. Eine Erzählung, Grotesche Verlagsbuchhandlung, Berlin 1921.

Federer, H. Wander- und Wundergeschichten aus dem Süden, Grotesche Verlagsbuchhandlung, Berlin 1924. 
Grześkowiak J., , Tajemnica to jest wielka”. Sakramentalne przymierze matżeńskie, Uniwersytet Opolski, Opole 2010.

Leon XIII, Arcanum divinae sapientiae, http://www.nonpossumus.pl/encykliki/ Leon_XIII/arcanum_divinae_sapientiae/ads.php (28.2.2018).

Levinas E., Totalität und Unendlichke.it. Versuch über die Exeriorität, Alber, Freiburg - München 1987

Oser H., Heinrich Federer. Aus Briefen und Erinnerungen, Räber, Luzern Leipzig 1928.

Seip J., Einander die Wahrheit hinüberreichen. Kriteriologische Verhältnisbestimmung von Literatur und Verkündigung, Echter Verlag, Würzburg 2002.

Stearns Eliot Th., Religia i literatura, w: Szkice literackie, red. W. Chwalewik, PAX, Warszawa 1963.

\section{Streszczenie}

Celem niniejszego artykułu jest analiza motywu małżeństwa sakramentalnego w twórczości literackiej szwajcarskiego duchownego rzymskokatolickiego, Heinricha Federera (1866-1928). Nie do uniknięcia są przy tym pytania o ideę promowania wartości chrześcijańskich poprzez dzieło literackie. Uwzględniony zostanie wpływ na twórczość Federera czasopisma kulturowego „Hochland” oraz odniesienia do propagowanej przezeń idei odrodzenia literatury czerpiącej swoje inspiracje $\mathrm{z}$ tradycji katolickiej. Utwory Federera, czytane poza macierzystym kontekstem (i niezależnie od pierwotnej recepcji), mogłyby zostać potraktowane jako małowartościowa proza obyczajowa, stąd nie bez znaczenia są odwoływania w niniejszym artykule do ówczesnego kontekstu kulturowo-religijnego.

Slowa kluczowe: Kościót katolicki, religia, proza, matżeństwo, sakrament

"More than Just Poetry".

The Sacramental Marriage in Heinrich Federer's Writings

\section{Summary}

This article presents marriage themes in the literary activity of a Swiss RomanCatholic priest Heinrich Federer (1866-1928). Inescapably, this raises questions concerning the very idea of being a writer, his public role, and the concept of promoting the Christian values through his writings. The work of Federer reveals the significant influence of the cultural journal "Hochland" on the author. It was propagating the idea of a revival of literature, getting its inspiration from the Catholic tradition. If read independently of its the original context and reception, the works by Federer might be perceived as some sort of inferior Christian, 
„TO WIĘCEJ NiŻ POEZJA”. MaŁŻEŃSTWO SAKRAMENTALNE W TWÓRCZOŚCI...

devotional literature. Therefore, this paper carefully takes into account relevant cultural and religious context.

Keywords: Catholic Church, religion, literarature, marriage, sacrament 